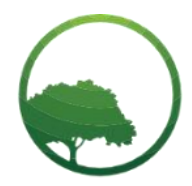

Research in Business \& Social Science

IJRBS VOL 10 NO 5 ISSN: 2147-4478

\title{
A critical review of the labor competitiveness as human capital in Indonesia
}

\section{Dewi Andriani}

Crossref

Ph.D., Lecturer at the Faculty of Economics Universitas Trisakti, Jakarta

\author{
ARTICLE INFO \\ Article history: \\ Received 02 July 2021 \\ Received in rev. form 27 July 2021 \\ Accepted 29 July 2021 \\ Keywords: \\ Labor Competitiveness, Human \\ Capital, Human Capital Mangement, \\ Indonesia \\ JEL Classification: \\ $\mathrm{O} 15, \mathrm{~J} 24$
}

\begin{abstract}
A B S T R A C T
This study aims to identify, rationalize and resolve the issue of labor competitiveness as human capital in organizations/companies from the perspective of human capital management in Indonesia. This study uses qualitative methods, observation or document study to collect data and analyze the data descriptively which is used to examine the condition of the object under study. The secondary data used in this study is aimed at supporting the primary information that has been obtained. The results of the study indicate that the competitiveness of the workforce as human capital is a workforce that has the ability to work, work skills and employability to develop a more effective and efficient work system in order to increase work productivity. This can be built and created through quality education and skills training programs based on information and communication technology (ICT) by encouraging vocational education and training, apprenticeships, and competency certification for students in the field of national education.
\end{abstract}

(C) 2021 by the authors. Licensee SSBFNET, Istanbul, Turkey. This article is an open access article distributed under the terms and conditions of the Creative Commons Attribution (CC BY) license (http://creativecommons.org/licenses/by/4.0/).

\section{Introduction}

At this time the competitiveness of the workforce is a critical issue in the Industry 4.0 era. The competitiveness of the workforce is generally interpreted as a workforce that has the ability to adapt, problem solving skills and technical knowledge which are the outputs of educational institutions and skills training. According to experts in Toner (2011) that the overall competitiveness of labor as human capital (Chulanova, 2017) has a strong causal relationship between the supply of higher levels of education, training and skills (Lloyd-Ellis \& Roberts, 2002). Skills education and training has a very positive impact on the wider economy as these institutions produce a trained and highly skilled workforce that is better prepared to face challenges and opportunities in the modern workplace in order to increase productivity, and promote broader economic growth (Digital Management and Leadership, 2018). The definition of human capital is basically education, professionalism and intelligence and higher education institutions are turning to the research university model to strengthen the interaction of education, science, and industry (Chulanova, 2017).

Technological changes and innovations encourage the development of a knowledge-based economy and their impact is on production methods, consumption patterns, and economic structure (Bassanini et.al., 2000). In the Industry 4.0 era, labor as human capital is directly involved in the entire production system as a system designer, as workers, and as customers of manufactured goods (Kinzel, 2017) so that workers who have the latest abilities and skills are very much needed in carrying out their duties. work (Gan \& Yusof, 2019; Sima \& Gheorghe, 2014). The application of new technologies and innovations generally tends to have an impact on the way of working and the ability of the workforce to increase work productivity and make a major contribution to the economic growth of organizations and countries (Erol et.al., 2016). Then, along with the spread of the Covid 19 pandemic throughout the world, it has become a biological phenomenon that threatens public health, thus triggering changes and transformations in all areas of life (Değer, 2021) including in the field of employment globally.

\footnotetext{
* Corresponding author.

(C) 2021 by the authors. Hosting by SSBFNET. Peer review under responsibility of Center for Strategic Studies in Business and Finance. https://doi.org/10.20525/ijrbs.v10i5.1303
} 
The business world today is increasingly faced with the problems of more complex changes, even the changes tend to be very fast and significant (Ibrahim et.al., 2019) in various fields such as economics, administration, social and politics which are important in society and the labor market in many ways. (Gruszczynski, 2020; Bhusal, 2020; Razif et al., 2020). According to The ASEAN Magazine (2020), information and communication technology and the outbreak of the Covid 19 pandemic have changed the nature of work and the way businesses operate, companies and individuals are increasingly turning to the digital economy to run businesses such as online transactions, ranging from banking services to purchasing goods and services. basic needs, are growing at a phenomenal rate and present a public health challenge for workplace safety and health to ensure all workers are in a safe working environment. In this situation and condition, the character of the work has changed so that the required skills (labor) have also changed. The implication of this change is that education or training must also change in order to increase the competitiveness of a competitive workforce in order to survive in these conditions.

In this context, the business world is forced to be able to respond to these changes by revising business processes, and one way that can be done is to increase the competitiveness of the workforce. According to von Hippel (2005) in Toner (2011), incremental innovation occurs both in direct business processes and in final consumption through ways such as workers and consumers adapting goods and services to better meet their particular needs and the feedback provided by groups of people. this group to manufacturers of equipment and services. In turn, the capacity to engage in such innovation has been shown to be highly dependent on the technological 'absorption capacity' of the workforce, which is broadly understood as the ability to adopt, adapt and deploy new or improved products, production processes and organizational innovations (Toner, 2003). 2011). According to data from the Central Statistics Agency/BPS as of February 2019 (https://www.bps.go.id.) the education of Indonesian workers is dominated by elementary school graduates and below as many as $\mathbf{5 2 . 4 0}$ million workers, thus making Indonesian workers still earn an income. low and unable to compete with neighboring countries.

According to research conducted by the Institute for Management Development (IMD) in Certificationku.com (18/7/2020) and the results of the 2015 national labor force survey processed by the Demographic Institute of the University of Indonesia, in Mahdiyah (2019) that problems related to the competitiveness of the workforce in Indonesia is the low level of education of workers and the mismatch between education and work. as follows :

i. Job mismatch with education level and wages (vertical mismatch) and job qualification mismatch with educational background (horizontal mismatch),

ii. The number of unemployed is increasing,

iii. Human resource competence is still not optimal, and

iv. Not yet maximal distribution of professional certification of workers.

Based on various descriptions of the background of the problem, this study aims to investigate, rationalize and resolve the competitiveness of the workforce as a competitive advantage of companies from the perspective of human capital management in Indonesia. The problem in this study can be formulated as follows: (1).Is the labor competitiveness a very important issue from the perspective of human capital management?,(2).How is the vertical mismatch horizontal mismatch in Indonesia?,(3).How is the description of the number of unemployment in Indonesia?, (4). How to maximize the laborer's competence in Indonesia?, and (5). Has the equity of Competency Certification been maximally implemented in Indonesia? This article is followed by a discussion of the research, discussion and results related to the questions raised in the 5 (five) formulations of this research problem.

Then, the object of this research is the workforce in Indonesia, the competitiveness of the workforce as human capital which is the competitive advantage of organizations/companies. This study uses qualitative methods, observations or document studies to collect data and analyze data descriptively (Moleong,2004) which is used to examine the condition of the object (Sugiyono, 2015) and investigate, find and describe the object under study (Anggraeni, \& Saryono,2013). The data collection technique used is library analysis which aims to find out theories, methods and approaches that can be studied related to "A critical review of labor competitiveness as human capital in Indonesia". Literature analysis as a data analysis technique serves to record carefully, carefully, and directed towards primary sources (Subroto in Al Ma'ruf,2010). Furthermore, the secondary data used in this study aims to support the primary information that has been obtained. Secondary data is in the form of library materials, literature, previous research, books, and so on (Hasan, 2002:58). This article ends with the results of the discussion and conclusions regarding a critical review of labor competitiveness in Indonesia

\section{Human Capital Management Perspective}

A qualified workforce or workforce that is competitive as human capital is the most valuable asset in organizations/companies and countries from the perspective of human capital management. According to Chulanova (2017), human capital is a factor in effective national economic development, and human capital can function as a valuable resource related to the mobility of knowledge and skills (Boon et.al., 2018). According to rnjar (2018), human resources as the main knowledge provider are the main factors in achieving sustainability and competitiveness in the global market. Human capital is an intangible asset because it includes all the competencies of people in an organization/company (Farrugia, 2017) who have significant participation in work, job switching and learning (Kinzel,2017;Kim et.al.2014;McIver et.al.,2013). Meanwhile, the knowledge, competence, and skills of workers are 
increasingly important due to the special characteristics of products and services, and this can be done through education, training, and information (Črnjar,2018).

According to The Global Competitiveness Report (2020) that: (1). The value of human capital is realized in the labor market through productive work, and developed through education and training to align incentives between workers and business - maintaining a close relationship between pay and productivity, meritocracy in salary and professionalization in company management as prerequisites for wider workforce productivity. According to Pelinescu (2016), the competitiveness of the workforce is a human resource that has an important role in competitive and sustainable economic development and as a development engine to achieve the welfare of companies and the state. According to Dunford and Snell (2001) in Kazlauskaitė \& Bučiūnienè (2008), human capital consists of: knowledge, skills, abilities, employee relations and behavior, psychological contracts and organizational citizenship, as well as people management practices (staff, training, rewards, appraisals). , work design, participation, recognition, and communication.

According to Srivastava and Das (2015), human capital management is a collection of human resources, which consists of all knowledge, talents, skills, abilities, experience, intelligence, judgment, and wisdom possessed individually and collectively by individuals and can be directed to achieve goals. organizational goals (Hatch \& Dyer, 2004; Memon et.al, (2009). According to Bubenik (2019), a company's competitive advantage can be interpreted as that the company is in a leading position among many other companies in the market with the indicators being excellence in quality, low cost, value or innovation by maximizing human resources (Shaw et.al.,2012; Bevacqua,2018; Bejaković,2014).According to the National Research Council in the United States in the OECD (2016), has identified three broad domains: cognitive domain, including cognitive processes, knowledge and creativity; intrapersonal domains, including intellectual openness, work ethic and self-confidence; and interpersonal domains personal skills, including teamwork, collaboration, and leadership.

Furthermore, the acceleration of business dynamics which is increasingly filled with competition due to advances in information and communication technology as well as the spread of the Covid 19 pandemic throughout the world which triggers changes and transformations in all areas of life, the workforce as human capital which has very strategic value, organizations/companies must can carry out education and training programs that aim to produce special skills, abilities, and innovations through education and skills training for technical and expert/professional capacity development (Bejaković,2014) through digitizing and optimizing the use of information and communication technology (Marek et.al.,2020). ICT-based high-quality education and training for the workforce can be interpreted as shown in Figure 1 below:

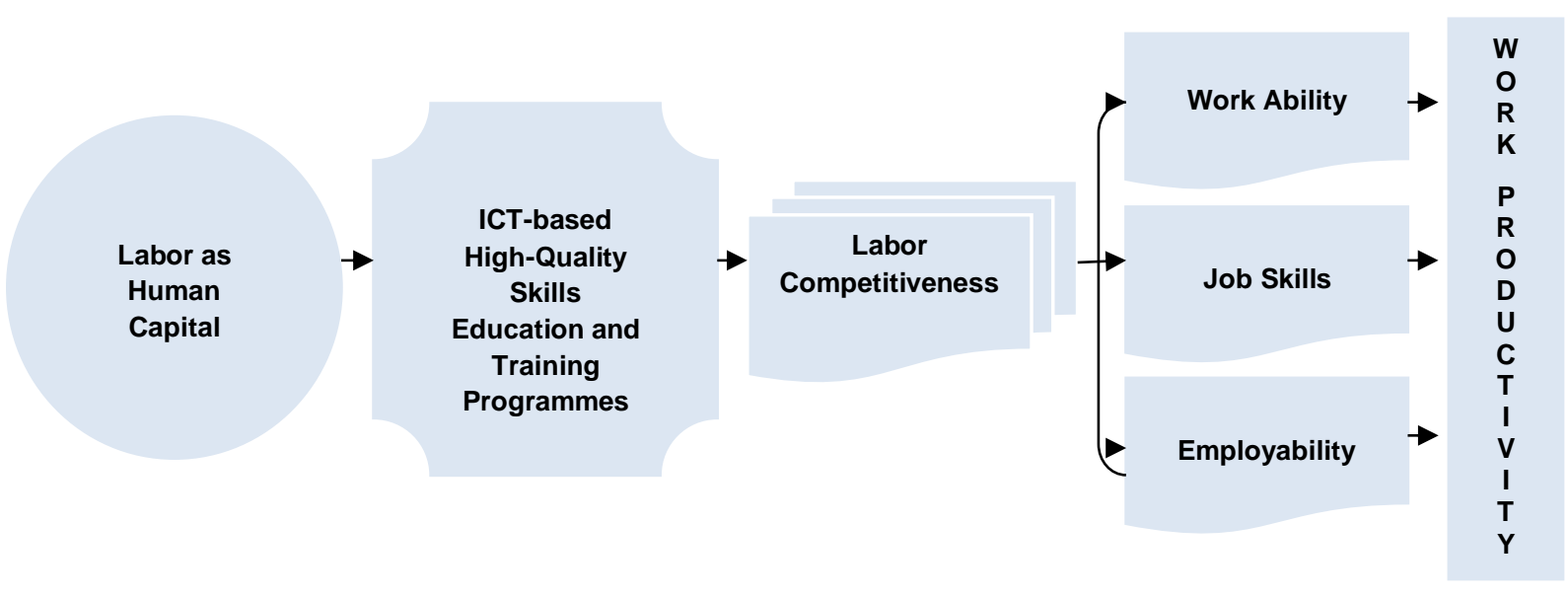

Figure 1: Labor Competitiveness from the Perspective of Human Capital Management

Based on Figure 1, it can be explained that the competitiveness of the workforce is human capital or organizational/company resources that have very strategic value and become one of the critical issues from the perspective of human capital management (HCM). According to Becker (1964) in Lee (2018), the theory of human capital is related to the knowledge and skills of individuals that can improve their cognitive abilities to be effective and efficient, which, in turn, enables them to be more successful in carrying out their activities at work in the workplace. an ever-changing environment (OECD,2016). According to Dumont and Istance (2010) in the OECD (2016), education and training have succeeded in building and creating workforce competitiveness by transforming knowledge, skills, and abilities to adapt to accelerated changes in the world of work (Bejaković,2014). Then, the scope of highquality ICT-based skills education and training materials includes: problem solving skills, communication skills, analytical skills, data analysis, critical judgment, time management, team work or social and emotional skills including working with others, managing emotions to achieve goals, work productivity (OECD,2016) 
From the various descriptions above, it can be interpreted that the competitiveness of the workforce from the perspective of human capital management is a workforce that has the work ability, work skills and employability to develop a more effective and efficient work system in order to increase work productivity. This can be built and created through high quality education and skills training programs based on information technology and communication (ICT). Thus, several indicators of labor competitiveness problems in Indonesia that are critically reviewed include the mismatch of work with education and wages (vertical mismatch) and mismatch of job qualifications with educational background (horizontal mismatch, number of unemployed; competence of human resources is still lacking). optimally, and the distribution of professional certification for the workforce has not yet been maximized. Manpower education and the mismatch or mismatch between education and work in the workforce are critical issues in the employment sector in Indonesia.

\section{Vertical and Horizontal Mismatch}

According to experts in Cabus and. Somers (2018), workplace education and training programs are mostly accepted by highly educated workers and are more likely to be conducted in technologically advanced industries to complement skills and support certain types of workers. According to Cappelli (2008) in Cabus and Somers (2018), companies can build and create workforce competitiveness, labor as human capital who has certain skills and competencies by developing them internally through high-quality ICT-based programs and training. According to the 2015 national labor force survey processed by the Demographic Institute of the University of Indonesia: in Mahdiyah (2019), the vertical mismatch or job mismatch with education level and wages reached 53.33 percent. Meanwhile, the horizontal mismatch or mismatch of job qualifications with educational background reached 60.52 percent as follows:

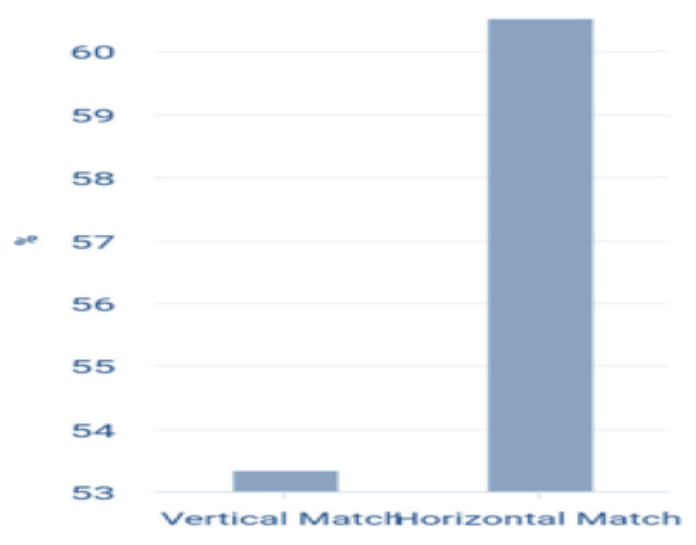

Figure 2: Education level and low wages (vertical mismatch) and workers and employment mismatch with education level and wages (horizontal mismatch upah (horizontal mismatch); Source: 2015 National Labor Force Survey processed by the

Demographic Institute of the University of Indonesia in Mahdiyah (2019)

Based on table 1 above, it can be interpreted that there is a gap in wrkers' education and a mismatch (mismatch) of work with education level and wages as well as a mismatch of job qualifications with educational background. This means that the education of Indonesian workers is still low and this must be handled in an integrated and comprehensive manner by the Government of Indonesia. Thus, there is a need for collaboration between relevant ministries and institutions, especially in the education and training sector in developing a curriculum that truly fits the needs and dynamics of the industry. This is a challenge for the Indonesian government to formulate and implement a comprehensive policy related to high quality ICT-based skills education and training. This policy must have a goal to produce the competitiveness of Indonesian workers, labor as human capital who has the skills and abilities to work globally. This can be done by encouraging vocational education and training, apprenticeships, and competency certification for students in the national education sector.

\section{The Number of Unemployment in Indonesia}

Population growth and employment growth in any country are important factors for economic development and become one of the big problems, namely unemployment (Singh,2021). including in Indonesia. According to Wijayanto and Ode (2019), unemployment is defined as the workforce who have not and are looking for work. While Singh (2021) states that people who carry out economic activities are called people who work while people who are looking for work are called unemployed people. Unemployment occurs due to a surplus of labor supply in the labor market and has an impact on the imbalance and mismatch between job demand and job supply, thus creating unemployment (Wijayanto and Ode,2019).

In Indonesia, the unemployment rate measures the number of people actively seeking work as a percentage of the labor force (Trading Economic,2021). According to Law No. 13 of 2003, labor is anyone who is able to do work to produce goods and services, both to 
meet the needs of themselves and others or the community. The corona virus pandemic (Covid-19) infects various lines of life, ranging from the health sector, the economy and various other lines of social life globally and also in Indonesia. National economic growth in the second quarter of 2020 was minus $5.32 \%$ and the employment sector, for example, had an impact on employees who were laid off until they were laid off (Ulya,2020) and triggered the unemployment rate. Demographically, Indonesia's population is 270.20 million people with an average annual population growth rate of 1.25 percent during 2010-2020 (Badan Pusat Statistik/BPS Indonesia, 2021). Based on data from the Central Statistics Agency/BPS Indonesia (2021) released on 25/5/2021, there are several indicators related to the demographics of Indonesia in 2021 as follows:

i. The total workforce in February 2021 was 139.81 million people, an increase of 1.59 million people compared to August 2020. In line with the increase in the number of workers, the working population was 131.06 million people, an increase of 2.61 million people from August 2020.

ii. Employment that experienced the largest percentage increase was the Accommodation and Food and Beverage Provision Sector ( 0.34 percentage point). Meanwhile, the sectors that experienced the biggest decline were the Transportation and Warehousing Sector $(0.30$ percentage point);

iii. A total of 78.14 million people (59.62 percent) worked in informal activities, down 0.85 percentage point compared to August 2020; and

iv. There are 19.10 million people (9.30 percent of the working age population) affected by Covid-19. Consists of unemployment due to Covid-19 (1.62 million people), Non-Work Force (BAK) due to Covid-19 (0.65 million people), temporarily not working due to Covid-19 (1.11 million people), and resident's workers who experienced a reduction in working hours due to Covid-19 (15.72 million people).

Referring to the Indonesian BPS data, the problem of job availability and the unemployment rate is a critical issue. Indonesia is among the thirty largest countries in the world (in terms of geographic area) and also among the countries with the largest population, behind China, India, and the United States and the unemployment rate in Indonesia from 1999 to 2020 (O'Neil, 2021), as follows:

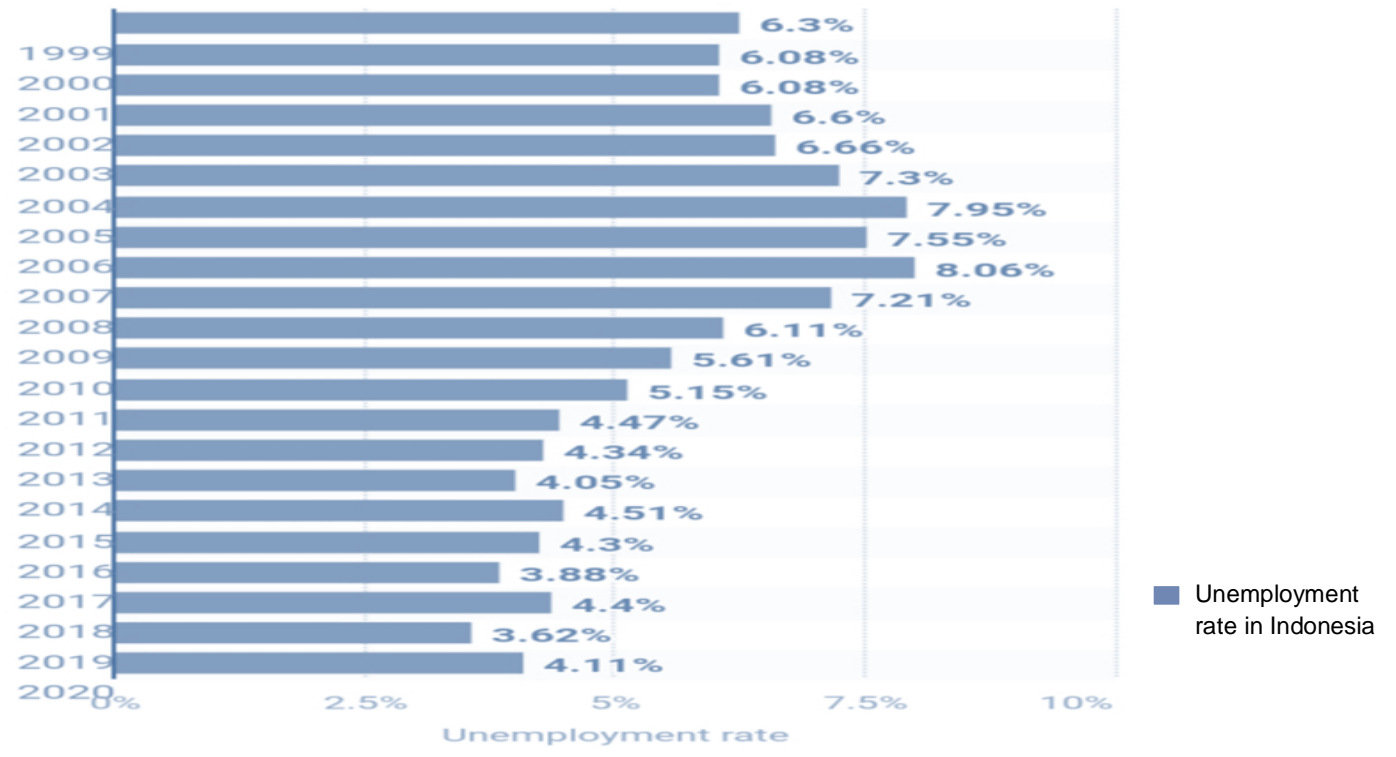

Figure 3: Indonesia: Unemployment Rate from 1999 to 2020; Source: The unemployment rate in Indonesia 2020 by O'Neill ,2021 (Processed)

Based on figure 3, it can be seen that the unemployment rate in Indonesia from 1999 to 2020, before the outbreak of the Covid 19 pandemic in Indonesia was as follows: $6.3 \%$ in $1999,6.08 \%$ in $2000,6.08 \%$ in 2001, $6.6 \% 2002,6.66 \%$ in $2003,7.3 \%$ in 2004 , $7.95 \%$ in $2005,7.55 \%$ in $2006,8.06 \%$ in $2007,7.21 \%$ in $2008,6.11 \%$ in $2009,5.61 \%$ in $2010,5.15 \%$ in $2011,4.47 \%$ in $2012,4.34 \%$ in $2013,4.05 \%$ in $2014,4.51 \%$ in $2015,4.3 \%$ in $2016,3.88 \%$ in $2017,4.4 \%$ in $2018,3.62 \%$ in 2019 , and $4.11 \%$ in 2020 . According to Trading Economic (2021) The number of unemployed in Indonesia continued to increase to 6.26 percent in the first quarter of 2021 from 4.94 percent in the same quarter of the previous year, amid the economic slowdown due to the coronavirus crisis as follows: (1). million to 8.75 million; (2). The number of workers decreased by 2.23 million to 131.06 million, mostly in the transportation and warehousing sector ( -0.30 percent) while the accommodation and food services sector experienced the largest increase ( 0.34 percent); and (3). The labor force participation rate fell to 68.08 percent in the first quarter from 69.21 percent in 2013 


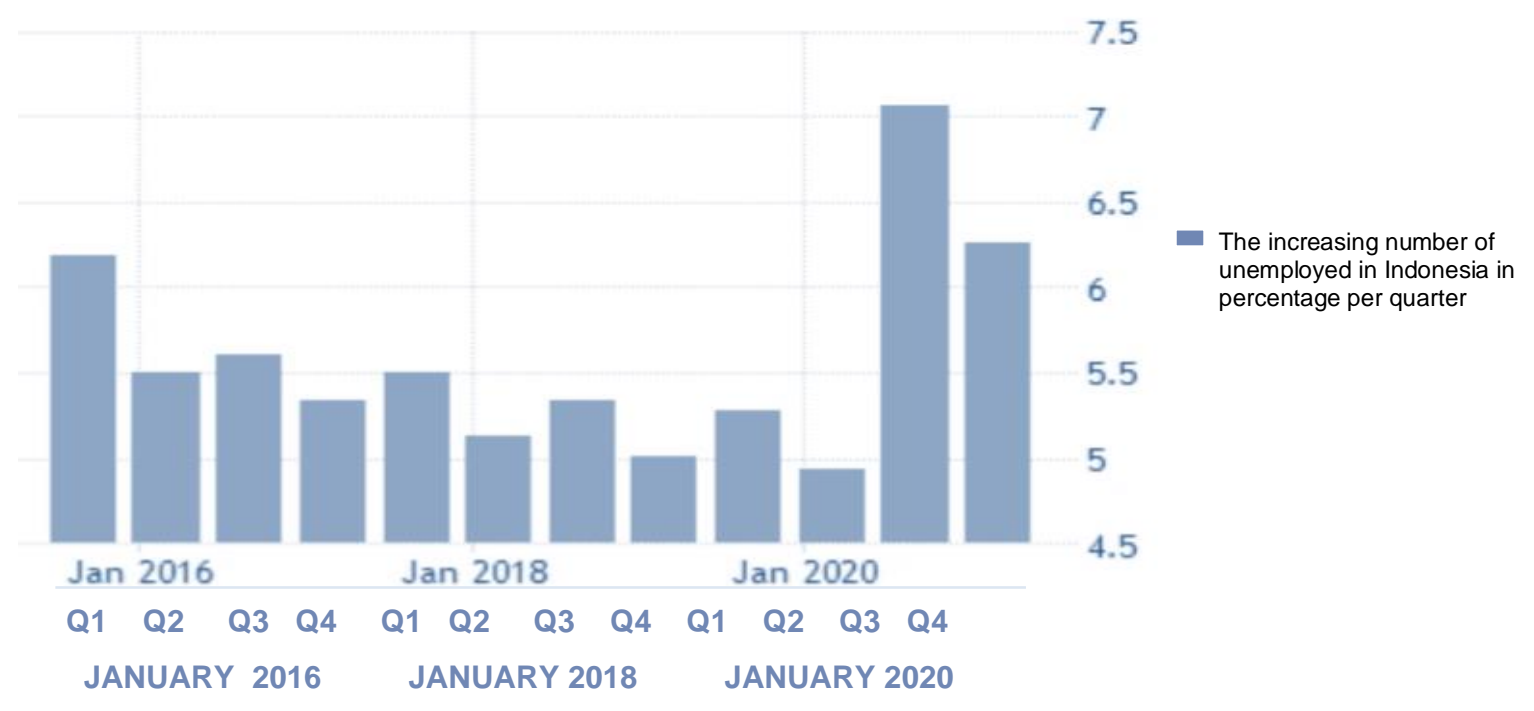

Figure 4: Unemployment in the midst of the economic downturn due to the Covid-19 pandemic crisis in Indonesia; Source: Trading Economics.Com/Statistic Indonesia (2021) (Processed)

The acceleration of advances in information and communication technology as well as the COVID-19 pandemic has an impact on the workforce, bearing the loss of jobs, especially for workers in the low-wage service industry globally in general and Indonesia in particular. Therefore, in this turbulent economic situation and condition, the competitiveness of the workforce, skilled labor as human capital is increasingly important from the perspective of human capital management (HCM) to be able to access job opportunities. In this context, the Indonesian government is expected to continue to increase the number of employment opportunities based on labor-intensive work, as has already begun. The people's infrastructure program with the Cash Intensive Work (PKT) scheme, which is implemented by the government through the Ministry of Public Works and Public Housing (PUPR) can continue to be communicated to all stakeholders to get full support from the wider community in Indonesia. The consistency and sustainability of the Cash-Intensive Scheme as a work program of the Ministry of PUPR is expected to be able to absorb labor, especially for workers in the low-wage service industry through infrastructure development that involves the community/local residents as development actors, especially small-scale infrastructure or simple jobs. Then, simultaneously the government immediately anticipates the development of human resources based on labor competitiveness. This can be done by the government by integrating the education sector and the industrial sector, strengthening links and matches, among others, by improving the quality of Indonesian human resources as a competitive workforce at the global level (Bappenas s Technical Draft: National Mid-Term Development Plan 20202024) . Economic development will be driven to grow taller, inclusive and competitive through: (1). Management of economic resources which includes the fulfillment of food and agriculture as well as management of marine, water resources, energy resources, and forestry; and (2). Acceleration of increasing added value of the agrofishery industry, maritime, energy, industry, tourism, as well as the creative and digital economy (Bappenas s Technical Draft: National Mid-Term Development Plan 2020-2024).

Based on the various descriptions above, it can be interpreted that in the context of conditions full of uncertainty, especially in the midst of the economic slowdown due to the corona virus crisis, extraordinary efforts are needed to mitigate the number of unemployment in Indonesia which tends to increase. Efforts that can be made by the government are to increase the competitiveness of Indonesian workers by involving all stake holders such as business people, academics, politicians, social institutions and the wider community. Then, open and improve the curriculum of Vocational High Schools (SMK) based on local wisdom and regional potential such as SMK majoring in Commerce, SMK majoring in Information and Communication Engineering, SMK majoring in Agriculture and Plantation, SMK majoring in Animal Husbandry and Fisheries, SMK majoring in Maritime, SMK majoring in Tourism, Vocational Schools majoring in Catering/Clothing/Ordering/Decoration and other SMKs are the key to reducing unemployment in Indonesia, the government must do in order to answer the challenges of unemployment. On the side for universities, the government can synergize the orientation of research-based universities and the application of science and technology. This is done by link and match with the industrial world. Then, labor competitiveness as a dynamic concept that considers the ability of organizations/companies to react to changing economic/technological conditions in order to maintain and increase work productivity through more dynamic education and training programs (United Nations, 2001).

\section{Maximizing the Competence of Indonesian Labor}

Indonesia experiences an oversupply of semi-skilled workers, and the education and training system does not provide students and job seekers with the right skills needed to perform the jobs available in the country (Asian Development Bank,2018). Based on the 
Global Human Capital Index by the World Economic Forum (WEF) 2017, the competitiveness ranking of Indonesian workers as human resources is in position 65 out of 130 countries, lagging behind Malaysia at 33, Thailand at 40, and Vietnam at 64 (Directorate General of Vocational Education,2020). Although Indonesia's labor productivity has increased, from 81.9 million rupiah/person in 2017 to 84.07 million rupiah/person in 2018, Indonesia's labor productivity is still lagging behind Singapore and Malaysia and only 2.8 percent growth The economy comes from capital capital and 1.5 percent from human capital (Directorate General of Vocational Education 2020). This condition identifies that the competitiveness of the Indonesian workforce has not been managed optimally so that this has become one of the critical issues from the perspective of human capital management. According to the Asian Development Bank (2020) that increasing productivity through human capital development programs focuses on economic growth through labor productivity which includes various aspects of human resource development, including education, skills development, health, and social assistance, all of which are packaged within the framework of Sustainable Development. Goals (SDGs). According to the experts in Varga et al. (2021), workforce competence is one of the key terms of human resource management because it helps answer the question of what factors are needed for employers and companies to have superior and competent employees (and with Thus, an efficient organization) that performs above average (Spencer \& Spencer, 1993 in Varga et.al.,2016). According to Carnevale et.al. (2020), competence is the knowledge, skills, and abilities that workers use in their work:

i. Knowledge includes principles and facts related to a particular content domain, from subjects taught in formal education to applied disciplines learned through practice,

ii. Skills are the vehicles that enable workers to successfully complete job tasks, to apply their useful knowledge, and to engage in further learning, and

iii. Ability is talent that affects performance; both innate and developed, as opposed to knowledge and skills, which are acquired over time

According to Scharle (2003), if competitiveness is defined as the potential for growth, the contribution of human resources to economic competitiveness, this is determined by the size of the competence of the workforce and the flexibility of the labor market. According to Varga et.al. (2016), workforce competencies consist of: communication in a foreign language, ICT skills, persistence, problem solving, ability to learn, flexibility, self-improvement, communication skills, endurance, technical skills, persuasion, entrepreneurial skills, learning from mistakes, economic skills, discretion, and self-discipline as well as talented people (Ready \& Conger,2007). Furthermore, Streeck (1989), Vickery and Wurzburg (1996) in Toner (2011) state that a competitive workforce in many companies in developed countries is a workforce that has the ability to adapt, has special skills and has quality in solving problems. in carrying out the work is proven to increase the company's work productivity. According to Agudelo \& Saavedra (2017), a competitive workforce is human capital that has unlimited potential to produce intelligence and talent as well as large resources for companies to implement technology. Therefore, a competitive workforce or a competent workforce is a very strategic agenda in the context of the application and utilization of advanced technology and electronic equipment. In the end, the workforce is human capital to make a very important and strategic contribution to business processes. According to experts in Bejaković (2014), the term competence covers a wide range of skills that are essential to securing and maintaining decent work. Then, from various surveys conducted by researchers, information was obtained that the competitiveness of Indonesian workers is still relatively low when compared to the competitiveness of several neighboring countries. The competitiveness of the Indonesian workforce is still relatively low due to the low quality of the workforce in Indonesia as a result of the low level of education.

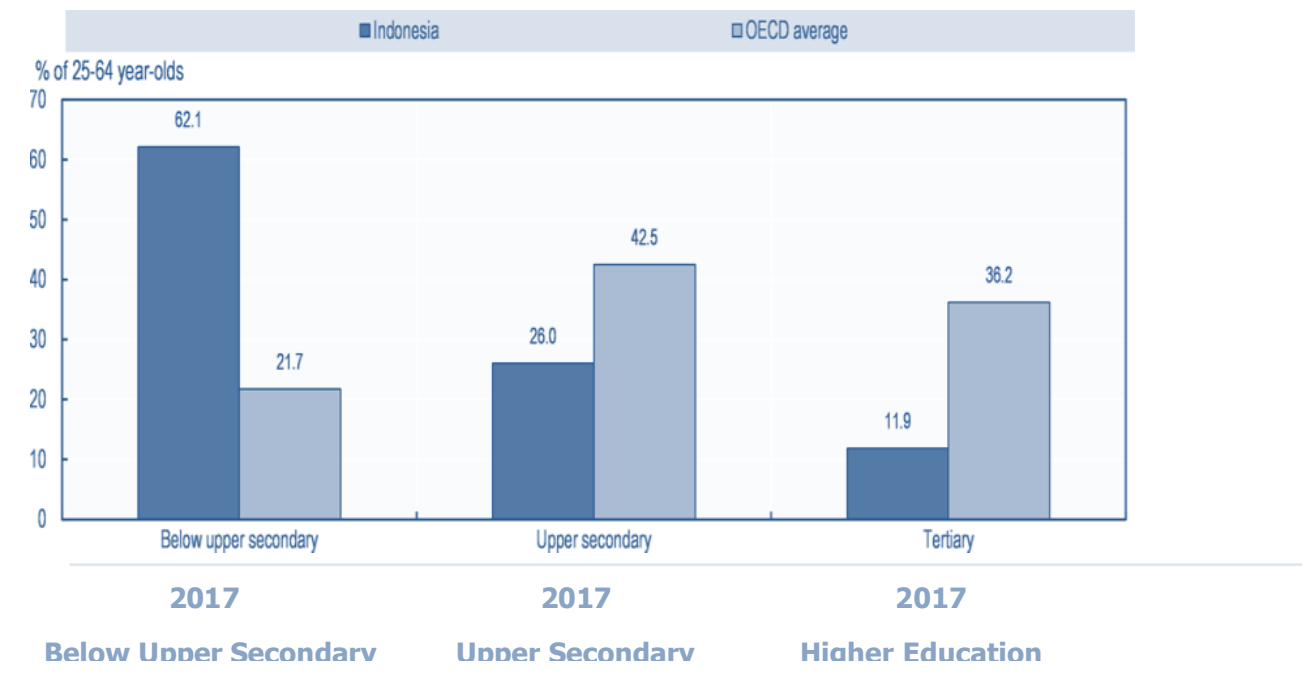

Figure 5: The Majority of the Indonesian Population attains below Upper Secondary Education; Source: The indicators of educational attainment of the workforce in Indonesia in percentage retrieved from OECD 2020 (Processed) 
Based on Figure 5, it can be seen that the indicators of labor education achievement in percentage (\%) in Indonesia aged 25-64 years and compared to the OECD average workforce education achievement indicators are as follows: (1).In 2017, the majority the population in Indonesia still has education below upper secondary of $62.1 \%$ compared to the OECD average workforce education achievement of $21.7 \%$; (2). Indonesian workers who achieve upper secondary education are $26 \%$ compared to the average workforce education at the Organization for Economic Co-operation and Development/OECD which is 42.5\%; and (3). Indonesian workers who achieve higher education (higher education) are $11.9 \%$ compared to the OECD average workforce education achievement of $36.2 \%$. This has implications for the low work competence and suitability of skills and job suitability. This indicator is one of the causes of unemployment in Indonesia in addition to other factors.

Therefore, efforts to increase productivity through the Human Resource Development Program focus on economic growth through labor productivity. This program covers various aspects of human resource development, including education, skills development, health, and social assistance which are all packaged within the framework of the Sustainable Development Goals (SDGs). Vocational Education Training can provide students and job seekers with the skills needed in the local labor market, and it is identified as a powerful tool to address development challenges and inequality in the ASEAN region (OECD,2018). Ensuring that people not only participate in and achieve higher skill levels but also access high quality training opportunities that narrow the gap between the supply and demand for skills in the labor market and can therefore be a driver of productivity growth in Indonesia, supporting the country's transition to higher levels of performance higher economy.

According to experts in Bejaković (2014) it is stated that employability is the main result of high-quality education, as well as various other policies covering skills, knowledge and competencies that enhance the ability of workers to: (1).Secure and retain jobs, (2).Progress at work and coping with change, and (3).Secure another job if he wants it or has been laid off, and enter the job market more easily. Furthermore, the International Labor Organization / ILO (2021), anticipation of workforce skills is needed to identify and prepare to meet future workforce competency needs in order to avoid potential gaps between demand and supply. Skills anticipation enables training providers, youth, policy makers, employers and workers to make better education and training choices, and through institutional mechanisms and information, leads to increased use of skills and human capital development (ILO,2021).

According to the Organization for Economic Co-operation and Development / OECD (2019), effective vocational education and training will be important to address skills gaps and shortages at the local level in Indonesia as follows: (1). Provide access to vocational training and opportunities, enable participants to acquire practical competencies, and will address the needs of related industries, including food and beverage, IT, sales and marketing, banking and finance, and agriculture; and (2). Skills enhancement for job seekers, workers, and people facing career transitions.

Based on various descriptions related to the competence of Indonesian workers, it can be interpreted that there is still a gap between the needs of the labor market and competency development. In other words, the competence of the workforce in Indonesia as human capital tends to be not optimally managed properly based on human capital management, either by organizations/companies or by the government. Therefore, the education sector is the main goal that must be strengthened, especially related to the quality of education. The education sector, both secondary and tertiary education, must be able to investigate and understand and respond to the needs of the industrial sector related to workforce competence and job availability. This can be done by ensuring that the educational curriculum is the reference in the education process so that it must be aligned with the qualification framework required by the Industrial sector. The industrial sector as a labor user generally determines the level of education and competence as a reference for providing work responsibilities, determining remuneration, careers and others within the organization/company. According to the Organization for Economic Co-operation and Development/OECD (2018), workforce competencies in the form of high skills, and higher skill levels tend to have better outcomes in the labor market and are more productive in their work.

Thus, Indonesia is expected to be able to increase the competitiveness of the Indonesian workforce through high-quality ICT-based education and skills training programs for the workforce. Along with the Covid-19 pandemic, this has become a more complex challenge for the government, especially increasing the competence of workers in Indonesia. Therefore, the government must be able to ensure that a sustainable education sector and improving learning outcomes in Indonesia is a must. This can be done by reviewing the curriculum and optimizing the utilization of information technology and technology in conducting distance learning and implementing competency certification that refers to the rules of the quality assurance system that apply internationally..

\section{Maximizing the Equity of Competency Certification In Indonesia}

In general, competency certificates can be interpreted as certifications that stipulate that a person has the necessary abilities to perform certain tasks related to work, employability. Job skills include soft skills and professional skills that enable individuals to succeed in the workplace (Doyle,2020). This can be proven by the individual having a certificate of competence. Competency certificates are given to individuals who have graduated from education and training programs from professional institutions. Professional institutions in question are educational and training institutions that have a widely agreed quality assurance framework as a benchmark used to evaluate quality assurance systems and processes.

The European Center for the Development of Vocational Training/Cedefop (2011) defines certification as the process of issuing a certificate, diploma, or degree of learning outcomes that formally proves that a series of learning outcomes (knowledge, knowledge, 
skills, and/or competencies) are acquired by individuals has been assessed and validated by a competent body against established standards.

Then, the European Center for the Development of Vocational Training / Cedefop (2011) explains that related to certification are as follows:

i. One of the most common types of certification systems related to human resource development is where a person is certified as capable of performing certain job tasks related to a job,

ii. Certification is generally based on an assessment, which generally includes a test, performance appraisal, and/or portfolio,

iii. Certification may include proof of work experience prior to assessment. Some certification systems cover a valid recognition period and therefore require recertification, whereas others undertake lifetime certification upon completion of all certification requirements, and

iv. Certification does not necessarily refer to the legal ability to practice in a particular profession; this is generally called a license. Usually licensing is based on a legislative instrument, is a government requirement, involves the protection of public safety, and is administered by a regulatory agency.

In this case, the competency certification program can be carried out by educational and training institutions by meeting various criteria as follows:

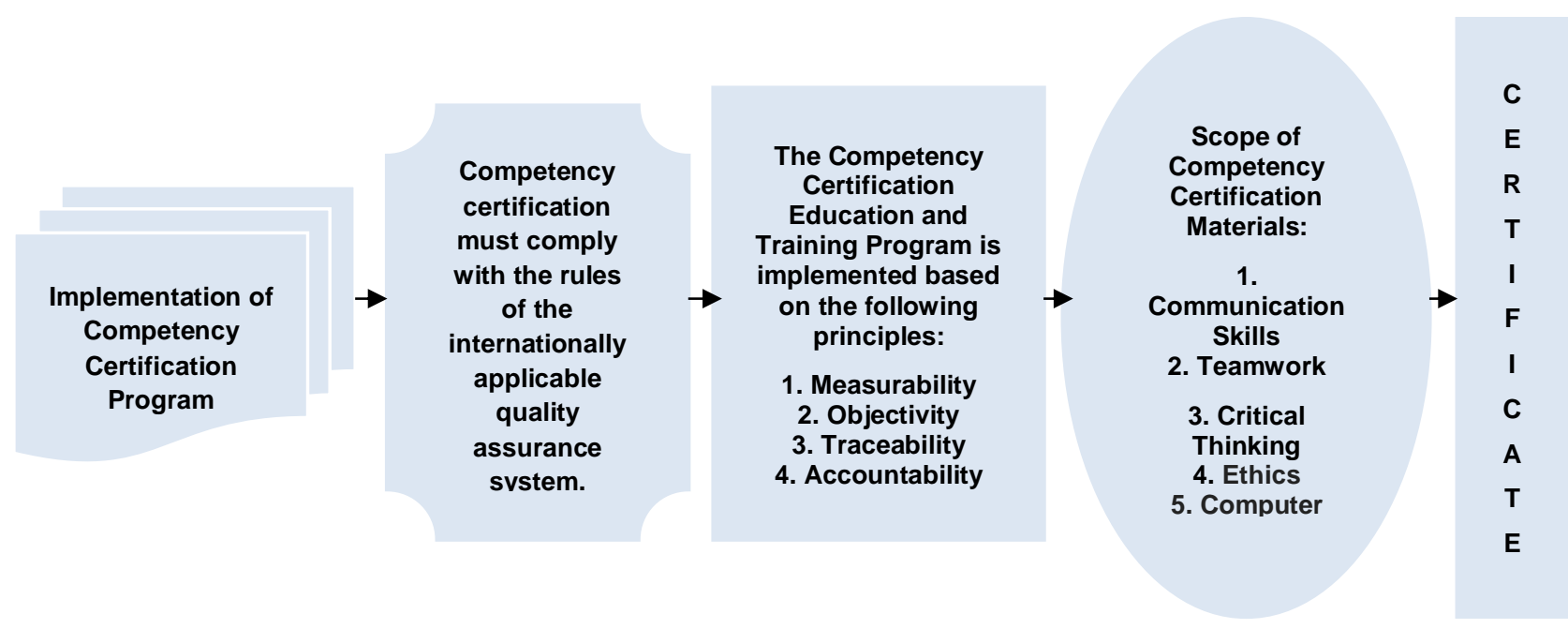

Figure 6. The Implementation of the Competency Certification Program

Based on Figure 6, it can be interpreted that what is meant by competency certification is an important guarantee of work competence, and the implementation of competency certification must comply with the rules of the internationally applicable quality assurance system (Organization for Economic Co-operation and Development/OECD,2019). Competency certification is carried out through standardized tests following the Indonesian National Work Competency Standards (INWCS), international or special standards, and the aim is to provide recognition of workforce skills (OECD,2019) as follows:

i. Measurability - provides clear benchmarks for competency certification. Competency certification can only be carried out for certain fields, types, and professional qualifications that have been determined in accordance with applicable regulations;

ii. Objectivity - ensuring competency certification is carried out without bias. For this reason, as far as possible the possibility of conflict of interest in the implementation of competency certification should be avoided;

iii. Traceability - ensures that the entire certification process from start to finish is clearly defined and can be easily, quickly and accurately tracked for monitoring and auditing purposes. For this reason, competency certification must refer to certain rules or guidelines and the process must be well documented; and

iv. Accountability - with the issuer of the certification being responsible to the community both technically, administratively, and juridically for the issuance of the certification.

Then, Doyle (2020) stated that the scope of material provided in the competency certification program so that labor competitiveness can be built and created are as follows: 
Table 1: Subjects and Scope of Learning Materials

\begin{tabular}{|c|c|c|}
\hline No & Subjects & Scope of Learning Materials \\
\hline 1 & Communication & $\begin{array}{l}\text { Strong communication skills such as: written communication, oral communication, interpersonal } \\
\text { skills, active listening and attentiveness. It refers to a person's ability to convey information clearly to } \\
\text { others. The labor must have strong written, verbal, and nonverbal communication skills besides that } \\
\text { the workforce must be able to be good listeners; can understand their clients' questions and concerns } \\
\text { and listen to their employer's directions }\end{array}$ \\
\hline 2 & Teamwork & $\begin{array}{l}\text { Each labor must be able to get along well with others and bear part of the workload and must be able } \\
\text { to work well with colleagues and managers. such as: collaborating, managing expectations, } \\
\text { implementing conflict management, reliability at work, and working professionally. }\end{array}$ \\
\hline 3 & Critical Thinking & $\begin{array}{l}\text { Each labor must be able to think critically such as the ability to understand, analyze, and interpret } \\
\text { information and draw conclusions. Therefore, the labor needs to think logically and make reasonable } \\
\text { judgments by having analytical skills, problem solving abilities, creativity, inductive reasoning and } \\
\text { deductive reasoning skills. }\end{array}$ \\
\hline 4 & Ethics & $\begin{array}{l}\text { Ethics is a broad category that refers to employee principles, namely the labor has compliance } \\
\text { (understands and follows company rules, is honest and trustworthy), integrity, empathy, wisdom, and } \\
\text { the ability to act professionally and responsibly. }\end{array}$ \\
\hline 5 & Computer Skills & $\begin{array}{l}\text { Job skills are soft skills whereas computer skills are hard skills required by the laborers in all } \\
\text { occupations. While some positions in technology such as software developer or IT specialist require } \\
\text { extensive programming knowledge. As for other laborers, where most of the work is needed, basic } \\
\text { knowledge related to computer applications is required. However, all laborers must demonstrate a } \\
\text { willingness to learn and adapt to the latest technology which has a rapidly changing nature. }\end{array}$ \\
\hline 6 & $\begin{array}{l}\text { More } \\
\text { Employability } \\
\text { Skills Examples }\end{array}$ & $\begin{array}{l}\text { Some of the other skills that must be possessed by laborers are as follows: Flexibility, Life Skills, } \\
\text { Motivation, Organization, Ability to Learn New Skills, Administrative Skills, Telephone Etiquette, } \\
\text { Customer Service, Client Relations, Presentation, Office Equipment, Bookkeeping Software, } \\
\text { Efficiency, Multitasking, Time Management, Sales, Goal Setting, Priority, Monitoring, Problem } \\
\text { Solving, Information Management, Initiative, Proactive, Focus, Enthusiasm, Negotiation, and } \\
\text { Memory }\end{array}$ \\
\hline
\end{tabular}

Source: Doyle,2020 (Processed)

According to Triana \& Rosmalia (2017), in general there are three general types of certification listed in order of development level and portability, namely company (internal), product-specific, and professional are as follows: (1). designed by the company or organization for internal needs. For example, a company may require a one-day training course for all sales personnel, after which they receive a certificate. While this certificate has limited portability especially for other companies;(2).Product certification, certification specifics are more involved, and are meant to be referenced to products in all applications. This approach is very common in the information technology industry, where personnel are certified in either software or hardware versions. The type of certification is portable on-premises (for example, different companies use the software), but not all other products; and (3). Professional certification, carried out for special competencies or expertise. For example, the medical profession often requires certain experts or specializations in providing services to patients, thus requiring a pattern of legal assessment and accountability from all existing professions.

In Indonesia, the implementation of competency certification has a legal umbrella as regulated in Presidential Regulation Number 8 of 2012 (Perpres 8/2012) concerning the Indonesian National Qualifications Framework which regulates work competency certification. According to Presidential Regulation 8/2012, work competency certification is a process of providing competency certificates that are carried out systematically and objectively through competency tests in accordance with the Indonesian National Work Competency Standards (SKKNI), International Standards, and/or Special Standards, and this certification system has the flexibility to harmonize with various national and international systems. Then, after the issuance of Presidential Decree 8/2012, the regulation regarding the implementation of the Indonesian National Work Competence (KKNI) was further regulated in various laws and regulations, including:

i. Law of the Republic of Indonesia No. 12 of 2012 concerning Higher Education

ii. Regulation of the Minister of Education and Culture of the Republic of Indonesia Number 73 of 2013 concerning the Implementation of the Indonesian National Qualifications Framework for Higher Education

iii. Regulation of the Minister of Education and Culture of the Republic of Indonesia Number 81 of 2014 concerning Diplomas, Certificates of Competence, and Professional Certificates of Higher Education 
iv. Regulation of the Minister of Home Affairs of the Republic of Indonesia Number 2 of 2013 concerning Guidelines for the Development of Competency-Based Education and Training Systems in the Ministry of Home Affairs and Regional Governments

v. Regulation of the Minister of Manpower and Transmigration, Republic of Indonesia Number 8 of 2014 concerning Guidelines for the Implementation of Competency-based Training; and

vi. Regulation of the Minister of Manpower, Republic of Indonesia Number 21 of 2014 concerning Guidelines for the Implementation of the Indonesian National Qualifications Framework

National Professional Competency Certification System is an arrangement of linkages between components of professional competency certification which includes the establishment of certification institutions, licenses, certification bodies, development of information systems for competency certification and synergistic and harmonious control of certification quality in order to achieve the objectives of implementing national work competency certification (Regulation of the National Certification Agency Profession No.1 Year 2015i/BNSP 01/2015). BNSP is a non-structural institution that has the authority to carry out certification in Indonesia, this is as explained in Government Regulation No. 10 of 2018. Then, in its implementation, BNSP has a Professional Certification Agency (LSP) which is licensed by BNSP to carry out professional certification. However, various problems related to competency certification in Indonesia at this time are the Government needs to ensure that the private sector has the competence and commitment to maintain that the process of testing and issuing competency certificates is carried out as stipulated by various laws and regulations as a legal umbrella in carrying out implementation. The Indonesian National Work Competency (KKNI) which aims to maintain the quality of the implementation of the competency test.

Therefore, the Professional Certification Institute (LSP) must have guidelines for assessing and monitoring performance as a mentor in implementing quality control of certification. This is important to do in order to ensure the performance and performance of the LSP with the following criteria: measurability, objectivity, and accountability - the certification issuer must be responsible to the community both technically, administratively, and juridically for the issuance of certification, be credible and have a valid license. both in terms of implementing the work competency certification program. Furthermore, the determination of the cost of competency testing should ideally be carried out by the Government, not jointly determined by business actors. This is necessary because the costs set by the Government will pay attention to a reasonable level of profit for business actors, but still consider the aspect of affordability for consumers.

Based on various descriptions related to maximizing equity, competency certification is an important issue from a human capital perspective because competency certification aims to build and create workforce competitiveness as human capital in Indonesia's national development. In the current context, the Indonesian nation is facing the challenge of catching up with other nations and this problem is getting more complex with the Covid-19 pandemic. Therefore, the development of the competitiveness of Indonesian workers, workers who have competitiveness in the international arena is a must.

Thus, to achieve the goal of developing the competitiveness of Indonesian workers, the emphasis is on development based on the economic sector with the competence of Indonesian workers as human capital. On the other hand, in order to achieve this goal, the government needs to carry out institutional supervision, where the intended institution is the Professional Certification Institute located in Indonesia which is very important and must be consistently monitored by the National Professional Certification Certification Agency (BNSP).

\section{Conclusions}

Technological change and innovation are driving the development of a knowledge-based economy and their impact is on production methods, consumption patterns, and the structure of the economy. Therefore, the business world needs to transform business processes due to advances in information and communication technology, especially with the outbreak of the Covid-19 pandemic, which requires qualified workforce specialists, workers who have competitiveness. The competitiveness of the workforce as human capital from the perspective of human capital management is a critical review because it is a top priority as a factor of excellence of a nation in facing global competition in the context of human development. This can be done by organizations/companies as well as the Indonesian government through structuring a comprehensive system of high-quality ICT-based education and skills training and its relevance to the needs of society and the world of work. In this context, the government has an important role in the implementation of an effective and efficient education and training system, oriented to the mastery of science and technology which is the current and future demands or needs of the market. Thus, policy synergies between stakeholders in related sectors and across sectors are also absolutely necessary in order to unite existing resources and potentials in order to accelerate the development of the competitiveness of Indonesian workers and maximize competency certification.

\section{References}

Al-Ma'ruf, A.I. (2010). Kajian Stilistika: Perspektif Kritik Holistik. Surakarta: UNS Press.

Agudelo,C.A.M., and Saavedra, M.R.B. (2016). The Human Resource Management As A Key Element And Quality Competitiveness Organizacional.Revista Científica "Visión de Futuro", 20(2), 21-37, Universidad Nacional de Misiones. https://www.redalyc.org/ journal/ 3579/ 357947335007/html/ 
Anggraeni,D.M. \& Saryono. (2013). Metodelogi Penelitian Kualitatif dan Kuantitatif dalam Bidang Kesehatan. Yogyakarta: Nuha Medika.

Asian Development Bank. (2020). Indonesia: Boosting Productivity Through Human Capital Development Program (Subprogram 1). Sovereign (Public) Project | 54461-001. https://www.adb.org/projects/54461-001/main

Badan Pusat Statistik (BPS) Indonesia.(2021). Hasil Sensus Penduduk 2020. https://www.bps.go.id/ pressrelease/2021/01/21/1854/hasil-sensus-penduduk-2020.html

Bappenas Rancangan Teknoratik : Rencana Pembangunan Jangka Menengah Nasional/RPJMN 2020-20242020-2024, https://www.bappenas.go.id

Bassanini, A., Scarpetta,S., and Visco, I. (2000). Knowledge, technology and economic growth: recent evidence from oecd countries. Working papers - $\quad$ research series. Nbb working $\quad$ paper No.6 https://www.econstor.eu/bitstream/10419/144220/1/wp006.pdf

Bejaković, P. (2014). Education, Employability and Labour Force Competitiveness in Croatia. Problems of Education in the $21^{\text {st }}$ Eentury. Volume 58, ISSN 1822-7864. http://www.scientiasocialis.lt/pec/ files/pdf/vol58/13-26.Bejakovic_Vol.58.pdf

Bevacqua,J.(2018). Developing a sustainable competitive advantage for their company is on the wish list of every CEO and business owner around the globe-but is it even possible? |May 24. https://risepeople.com/blog/company-culture-competitiveadvantages/

Bhusal, M. K. (2020). The world after COVID-19: An opportunity for a new beginning. International Journal of Scientific and Research Publications, 10(5), 735-741. https://doi.org/10.29322/ IJSRP.10.05.2020.p10185

Badan Pusat Statistik /BPS per Februari 2019 . https://www.bps.go.id/publication/2019/05/31/ a96ce41f72e59d5dfb1cad9f/keadaanangkatan-kerja-di-indonesia-februari-2019.html

Boon, C.,Eckardt, R.,Lepak, D.,\& Boselie, P.(2018). Integrating strategic human capital and strategic human resource management. The International Journal of Human Resource Management Volume 29, - Issue 1: Annual Review Pages 34-67 | https://doi.org/10.1080/ 09585192.2017.1380063

Bubenik,S.(2019).Can HR Strategies Create A Competitive Advantage For Your Company?.IFeb 18. https://www.forbes.com/sites/scholleybubenik/

Carnevale, A.P.,Fasules, M. L., and Campbell,K.P. (2020) Workplace Basics The Competencies Employers Want. https://www.luminafoundation.org/wp-content/uploads/2020/11/workplace-basics.pdf

Chulanova, Z. K. (2017). The Human Capital as a Factor of Competitiveness and Economic Development. East Asian Journal of Business Management 7-3, 23-31 ISSN 2234-3059. https://doi:10. 13106 /eajbm.2017

Cedefop (2011).Europen Centre for the Development of Vocational Training: Annual Report 2011. Luxemburg: Pubicatios Office of the European Union. www.cedefop.europa.eu

Črnjar, K.(2018). Human Capital Capabilities for Sustainable Competitive Advantage in Tourism Industry. EBEEC 2018. https://doi.org/10.18502/kss.v3i10.3535 https://knepublishing.com/index.php/Kne-Social/ article/view/3535/7415

Değer, V.B. (2021). Outbreak Management and COVID-19 Pandemic. IntechOpen, Published: March 4th. https://doi.org/10.5772/intechopen.96335. https://www.intechopen.com/about-intechopen

Digital Management and Leadership.(2018).What's the Importance of Higher Education on the Economy?. https://digitalmarketinginstitute.com/blog/what-is-the-importance-of-higher-education-on-the-economy

Direktorat Jenderal (Ditjen Pendidikan) Vokasi. (2020). Rencana Strategis (Renstra) Direktorat Jenderal Pendidikan Vokasi (Ditjen Pendidikan Vokasi) tahun 2020-2024

Doyle, A. (2020). What Are Employability Skills? - Definition \& Examples of Employability Skills. https://www.thebalancecareers.com/employability-skills-list-and-examples-4143571

Dubra, I.(2019).Human Capital Impact on The Enterprise Competitiveness. Conference Paper at University of Latvia, January 2019. https://www.researchgate.net/publication/330534240

Erol, S.;Jäger,A.;Hold,P.;Ott, K.; Sihn,W.(2016).Tangible Industry 4.0: A Scenario-Based Approach to Learning for the Future of Production. Procedia CIRP 2016, Vol.54, pp 13-18. https://doi.org/ 10.1016 /j.procir.2016.03.162

Farrugia,N.(2017).Competitive advantage through human capital. September 10, https://timesofmalta.com/ articles/view/Competitive-advantage-through-human-capital.657666

Gan, J.L.,\& Yusof,H.M.(2019).Industrial Revolution 4.0: the Human Resource Practices. International Journal of Recent Technology and Engineering (IJRTE), 8, 620-624. Issue-3S2, October, ISSN: 2277-3878. https://doi.org/10.35940/ijrte.C1203.1083S219

Gruszczynski, L. (2020). The COVID-19 Pandemic and International Trade: Temporary Turbulence or Paradigm Shift? European Journal of Risk Regulation, 11(2), 337-342. https://doi.org/10.1017/err.2020.29

Hasan, M. I. (2002). Pokok-pokok Materi Metodologi Penelitian dan Aplikasinya. Bogor:Ghalia Indonesia

Hatch, N. W., \& Dyer, J. H. (2004). Human capital and learning as a source of sustainable competitive advantage. Strategic Management Journal, 25, 1155-1178. https://doi.org/10.1002/smj.421

Ibrahim,M.S., Hanif, A., Jamal, F.Q., Ahsan, A. (2019). Towards successful business process improvement - An extension of change acceleration process model. PLoS ONE 14(11): e0225669. https://doi.org/10.1371/journal.pone.0225669

International Labour Organization/ILO.(2021).Skills strategies for future labour markets. https://www.ilo.org/ skills/areas/skillstraining-for-poverty-reduction/lang--en/index.htm

Kazlauskaitė,R.,Bučiūnienè,I.(2008).The Role of Human Resources and Their Management in the Establishment of Sustainable Competitive Advantage. ISM Vadybos ir ekonomikos universitetas E.Ožeškienès g.18, LT-44254, Kaunas Published in Engineering Economics 2008. No 5 (60). https://www.researchgate.net/publication/257294800

Kementerian PUPR. (2021). Buka Kesempatan Kerja, Program Padat Karya Bidang Jalan \& Jembatan Sudah Serap 109.047 Tenaga Kerja. https://www.pu.go.id/berita/buka-kesempatan-kerja-program-padat-karya-bidang-jalan-jembatan-sudah-serap109047-tenaga-kerja 
Kim, H., Hoskisson, R. E., \& Lee, S.-H. (2014). Why strategic factor markets matter: "New" multinationals' geographic diversification and firm profitability. Strategic Management Journal, 36, 518-536. https://doi.org/10.1002/smj.22

Kinzel, H. (2017). Industry 4.0 - Where Does This Leave the Human Factor? 15, 70-83, Technische Universitat Bergakedemie Freiberg, Germany. https://doi.org/10.14456/ jucr.2017.

Lee, B. (2018). Human capital and labor: the effect of entrepreneur characteristics on venture success. International Journal of Entrepreneurial Behavior \& Research. https://doi.org/:10.1108/ijebr-10-2017-0384

Mahdiyah,L. (2019). Ketidaksesuaian antara Pendidikan dan Kebutuhan Tenaga Kerja Masih Besar. https://databoks.katadata.co.id.

Marek,D., Patrik, R., Veronika, G., and Marina,F. (2020). Economic impacts of Covid-19 on the labormarket and human capital.. Terra Economicus, 2020, 18(4), 78-96. https://doi.org/10.18522/2073-6606-2020-18-4-78-96

McIver, D., Lengnick-Hall, C. A., Lengnick-Hall, M. L., \& Ramachandran, I. (2013). Understanding work and knowledge management from a knowledge-in-practice perspective. Academy of Management Review, 38(4), 597-620. https://doi.org/10.5465/amr.2011.0266

Memon, M.A., Mangi, R,A.,and Rohra, C.L. (2009). Human Capital a Source of Competitive Advantage "Ideas for Strategic Leadership". Australian Journal of Basic and Applied Sciences, 3(4): 4182-4189, ISSN 1991-8178 https://www.researchgate.net/publication/292417825

Moleong, L.J. (2005). Metodologi Penelitian Kualitatif, Bandung: Remaja Rosdakarya.

Organisation for Economic Co-operation and Development /OECD. (2016). Panel 4.2 "Skills for a Digital World" of the OECD Ministerial Meeting on the Digital Economy, 21-23 June, Cancún (Mexico). OECD digital economy papers No. 250. https://www.oecd-ilibrary.org/docserver

Organisation for Economic Co-operation and Development /OECD. (2020). Fostering local approaches to skills in Indonesia. https://www.oecd-ilibrary.org/sites/df6c4fbb-en/index.html?itemId=/content/ component/ df6c4fbb-en

Organisation for Economic Co-operation and Development/OECD (2020), Adult education level (indicator). https://doi.org/10.1787/36bce3fe-en

O'Neill, A. (2021). Indonesia: Unemployment rate from 1999 to 2020. , Jul 1. https://www.statista .com

Peraturan Presiden (Perpres) Nomor 8 Tahun 2012 Tentang Kerangka Kualifikasi Nasional Indonesia

Peraturan Menteri Pendidikan Dan Kebudayaan Republik Indonesia Nomor 81 Tahun 2014 Tentang Ijazah, Sertifikat Kompetensi, dan Sertifikat Profesi Pendidikan Tinggi

Peraturan Menteri Dalam Negeri Republik Indonesia Nomor 2 Tahun 2013 Tentang Pedoman Pengembangan Sistem Pendidikan dan Pelatihan Berbasis Kompetensi di Lingkungan Kementerian Dalam Negeri dan Pemerintahan Daerah;

Peraturan Menteri Tenaga Kerja dan Transmigrasi, Republik Indonesia Nomor 8 Tahun 2014 Tentang Pedoman Penyelenggaraan Pelatihan berbasis Kompetensi

Peraturan Menteri Ketenagakerjaan, Republik Indonesia Nomor 21 Tahun 2014 Tentang Pedoman Penerapan Kerangka Kualifikasi Nasional Indonesia

Pelinescu, E. (2016). Human Capital And Competitiveness In Ue, Internal Auditing and Risk Management, Athenaeum University of Bucharest, vol. 43(1), pages 49-61, September. https://ideas.repec.org/a/ath/journl/v43y2016ilp49-61.html

Razif, M., Miraja, B. A., Persada, S. F., Nadlifatin, R., Belgiawan, P. F., Redi, A. A. N. P., Lin, S-Ch. (2020). Investigating the role of environmental concern and the unified theory of acceptance and use of technology on working from home technologies adoption during COVID-19. Entrepreneurship and Sustainability Issues, 8(1), 795-808. http://doi.org/10.9770/jesi.2020.8.1(53)

Ready, D. A., \& Conger, J. A. (2007). Make your company a talent factory. Harvard Business Review, 85, 68-77. https://www.researchgate.net/publication/6255924_Make_your_company_a_talent_factory

Scharle, A. (2003). Competitiveness and the Labor Market. Working Paper No. 4 Strategic Analysis Division - The Ministry of Finance of Hungary. http://www.pm.gov.hu

Sertifikasiku. (2020). Daya saing tenaga kerja Indonesia masih ketinggalan! Yakin siap bersaing di era MEA?. 18 Juli. https://sertifikasiku.com/daya-saing-tenaga-kerja-indonesia-masih-ketinggalan-yakin-siap-bersaing-di-era-mea/

Shaw,J.D., Park,T.Y., and Kim, E. (2012). A resource-based perspective on human capital losses, HRM investments, and organizational performance. Strategic Management Journal Strat. Mgmt. J., 34: 572-589 (2013) Published online Early View in Wiley Online Library (wileyonlinelibrary.com) https://doi.org/10.1002/smj.2025

Singh, S.N. (2021). Unemployment in India: Causes and Solutions.International Journal of Humanities and Social Science Invention (IJHSSI) |10(4), 45-48 https://doi.org/10.35629/7722-1004024548 www.ijhssi.org 45

Sima, V., \& Gheorghe, I.G. (2014).Labour market trends in România in the context of green economy. Annals of the „Constantin Brâncuşi” University of Târgu Jiu, Economy Series, Special Issue/2014- Information society and sustainable development, pp. 116-123. https://www.utgjiu.ro/revista/ ec/pdf/2014-04.Special/22_Sima,\%20Gheorghe.pdf

Srivastava, K., and Das R. C.(2015). Human capital management: Economics of psychological perspective. Ind Psychiatry J. 2015 Jul-Dec; 24(2): 115-118. https://doi.org/10.4103/0972-6748.181717

Sugiyono. (2015).Statistika Untuk Penelitian. Bandung :CV Alfabeta

The ASEAN Magazine.(2020). The Inside View Human Resources Development. The ASEAN Secretariat ASEAN Socio-Cultural Community Department ,Jakarta, Indonesia , 4, https://asean.org/asean-socio-cultural/

The Global Competitiveness Report. (2020).: How Countries are Performing on the Road to Recovery. Special Edition 2020. Section 2: Human Capital. Published: 16 December 2020. https://www.weforum.org/reports/the-global-competitiveness-report2020\#report-nav

Toner,P. (2011). Workforce skills and innovation: an overview of major themes in the literature. Sg/innov(2011)1, 4-64. OECD Directorate for Science, Technology and Industry (STI) Centre for Educational Research and Innovation (CERI). https://www.oecd.org/ sti/inno/ 46970941.pdf 
Trading Economic.(2021). Indonesia Unemployment Rate. https://tradingeconomics.com/indonesia /unemployment-rate

Triana, H.,\& Rosmalia, e. (2017). Pengembangan Kualitas SDM Indonesia dengan Sertifikasi Profesi. https://lspipi.org/pengembangan-kualitas-sdm-indonesia-dengan-sertifikasi-profesi

Ulya, F.N.(2020). Pertumbuhan Ekonomi RI Minus 5,32 Persen pada Kuartal II-2020. https://money.kompas.com/read/2020/08/05/ 120854826/pertumbuhan-ekonomi-ri-minus-532-persen-pada-kuartal-ii-2020.

Undang-Undang Nomor 13 Tahun 2003 tentang Ketenagakerjaan

Varga,E., Szira,Z., Bardos, K.I., \& Hajos, L (2016). The Most Relevant Labour Market Competencies for Employers and their Assessment by Students. Practice and Theory in Systems of Education, 11 (2): 95-104. https://doi.org/10.1515/ptse-20160012

Wijayanto,H.,Ode,S.(2019). Dinamika Permasalahan Ketenagakerjaan dan Pengangguran di Indonesia. .Administratio, Jurnal Ilmiah Administrasi Publik dan Pembangunan. 10(1), https://media.neliti.com/media/publications/290285-the-dynamics-of-theproblem-employ ment-a-04d0b11e.pdf

Publisher's Note: SSBFNET stays neutral with regard to jurisdictional claims in published maps and institutional affiliations.

\section{(1) (1)}

(C) 2021 by the authors. Licensee SSBFNET, Istanbul, Turkey. This article is an open access article distributed under the terms and conditions of the Creative Commons Attribution (CC BY) license (http://creativecommons.org/licenses/by/4.0/).

International Journal of Research in Business and Social Science (2147-4478) by SSBFNET is licensed under a Creative Commons Attribution 4.0 International License. 